\title{
Loss of suppressor T-cells in active inflammatory bowel disease
}

\author{
N J GODIN, D B SACHAR, R WINCHESTER, C SIMON, AND H D JANOWITZ
}

\begin{abstract}
From the Division of Gastroenterology, Department of Medicine. The Mount Sinai Hospital, and the Laboratory for Cellular Mechanism of Disease. Hospital for Joint Diseases, Mount Sinai School of Medicine of the City University of New York. New York, NY, USA
\end{abstract}

SUMMARY The proportions and absolute numbers of helper and suppressor T-cells in 40 patients with inflammatory bowel disease and 22 control subjects were determined, using the monoclonal antibodies OKT 4 and OKT 8. There were no significant differences in helper or suppressor cell proportions among 15 steroid treated patients with active inflammatory bowel disease, 10 patients with inactive inflammatory bowel disease, 10 patients with other gastrointestinal diseases, or 12 normal control subjects. In contrast, 15 patients with active inflammatory bowel disease not treated with corticosteroids manifested increased proportions of helper cells and decreased proportions of suppressor cells $(p<0 \cdot 001)$, compared with all other patient groups and to normal controls. When absolute numbers of helper and suppressor subsets were measured, these alterations in proportions of helper and suppressor cells were primarily attributable to decreased counts of suppressor T-cells both in patients with active Crohn's disease and in those with ulcerative colitis $(\mathrm{p}<0 \cdot 01)$. In four patients undergoing serial study, the helper/suppressor ratios appeared to rise and fall respectively with clinical exacerbations and remissions of disease. These data provide additional evidence for the involvement of cellular immune systems in these disease processes.

\begin{abstract}
Abnormalities in cellular and humoral immunity have been frequently described among patients with Crohn's disease and ulcerative colitis. ${ }^{1-3}$ The recent development of monoclonal antibody methodology has provided a new insight into the $T$-cell sublineages involved in immune regulation and effector response. The T-cell sublineage characterised by the expression of T 4 or Leu 3 is usually, albeit with some exceptions, associated with the helper or inducer function, while T 8 or Leu 2 is expressed by cells of the sublineage usually involved in cytotoxic or suppressor function. Imbalances in these immunoregulatory $\mathrm{T}$-cell subsets have been reported in several diseases of unknown aetiology sharing some immunological abnormalities with inflammatory bowel disease, such as pulmonary sarcoidosis, multiple sclerosis, systemic lupus erythematosus, and primary biliary cirrhosis. ${ }^{+9}$

In order to determine whether alterations in these
\end{abstract}

Address for correspondence: Dr Norman Godin. Division de Gastroenterologie. Hospital Cantonal Lniversitaire. Geneva. Switzerland.

Received for publication 12 August 1983 sublineages occur in the course of inflammatory bowel disease, we have used monoclonal OKT 4 and OKT 8 antibodies to measure the proportions and absolute numbers of these T-cells subsets in 40 patients with various clinical patterns of inflammatory bowel disease and in 22 control subjects.

\section{Methods}

\section{SUBJECTS}

We studied 40 patients with inflammatory bowel disease treated at the Mount Sinai Medical Center between 1 July 1981, and 30 June 1982. There were 19 men and 21 women, with a mean age of 34 years (range 18-80 years old), and a mean disease duration of 11 years (range six months to 33 years). Twenty eight patients had Crohn's disease and 12 had ulcerative colitis.

The diagnosis was confirmed by clinical, radiographic, endoscopic, and pathologic criteria as previously described." "1" Crohn"s colitis was distinguished from ulcerative colitis by criteria outlined in our previous studies. ${ }^{12}$ 
These 40 patients were divided into three groups according to disease activity and corticosteroid therapy. Group A comprised 15 patients with active disease not treated with corticosteroids; group B consisted of 15 patients with active disease treated with corticosteroids; and group $\mathrm{C}$ was composed of 10 patients with inactive disease. Active disease (Groups A and B) was defined by complaints of more than three loose bowel movements a day, fever, and abdominal pain, as well as by actively inflamed and friable rectal mucosa on sigmoidoscopy for patients with ulcerative colitis. Patients on corticosteroids (Group B) all had had at least 10 days of intravenous or oral corticosteroid therapy immediately before sampling, while patients without corticosteroid therapy had had neither rectal nor systemic corticosteroids for at least one month prior to sampling. Two patients with corticosteroids and active disease were also on azathioprine at the time of study.

Inactive disease patients in group $\mathrm{C}$ had no more than three bowel movements, no fever, and no abdominal pain. Six ulcerative colitis patients all had normal mucosa on sigmoidoscopy; four patients with Crohn's disease were all one month to 33 years after surgical resection of all macroscopic disease, with no evidence of recurrence. None of the patients with inactive disease was being treated with corticosteroids. Sulphasalazine was being taken by six patients in group $\mathrm{A}$, three in group $\mathrm{B}$, and five in group $\mathrm{C}$.

There were two control populations. Group D consisted of 10 patients with diseases of gut and liver: one with appendiceal abscess, one with diverticulitis and fistulae, two with colon carcinomas, two with peptic ulcer disease, two with alcoholic cirrhosis and oesophageal varices, one with peptic oesophageal stricture, and one with irritable bowel syndrome. Group E comprised 12 healthy volunteers, sex and age matched with the inflammatory bowel disease patients in group $\mathrm{A}$.

\section{LYMPHOCYTE ANALYSIS}

Mononuclear cells were separated from $30 \mathrm{cc}$ of heparinised peripheral venous blood by centrifugation upon a Ficoll (Pharmacia, Inc., Piscataway, NJ)/Hypaque (Winthrop Laboratories, NY) density gradient. T-lymphocytes were obtained by rosette isolation $^{13}$ using neuraminidase (Behringwerke, Marburg, West Germany) treated sheep red blood cells. The viability of all cell preparations determined by trypan blue exclusion exceeded $98 \%$. The purity of the T-cell preparation was checked with a pan-T-cell murine monoclonal antibody (Orthoclone OKT 3, Ortho Pharmaceuticals, Raritan, NJ). All T-cell preparations were more than $95 \%$ positive. The absolute number of T-cells was determined by multiplying the percentage of rosette forming cells obtained by analytical E-rosettes by the total lymphocyte count obtained on routine white blood count and differential.

The relative proportions of the two sublineages in the T-lymphocyte suspensions were identified using murine monoclonal antibodies (Orthoclone OKT 4 for 'helper' cells and OKT 8 for 'supressor' cells, Ortho Pharmaceuticals) that have previously been shown to be specific to these T-cell subsets. ${ }^{14-18}$ The monoclonal reagents were used in an indirect immunofluorescence assay to stain the T-cells. Binding of the monoclonal antibodies was detected by $F\left(a b^{\prime}\right) 2$ fragments of a rabbit anti-mouse serum conjugated with tetramethylrhodamine isothiocyanate. Slides were examined using incident illumination in a fluorescence microscope (Leitz, Wetzlar, West Germany). Two hundred cells were counted for each specimen, with a reproducibility of $\pm 10 \%$ on repeated assays of single samples.

STATISTICAL EVALUATION

The Wilcoxon's rank sum test comparing two groups in independent samples was used. A p value of $<0.05$ was considered significant.

\section{Results}

As shown in Table 1, there were no significant differences in proportions of $\mathrm{T} 4(+)$ and $\mathrm{T} 8(+)$ T-cells among 12 normal control subjects (Group E), 15 patients with inactive inflammatory bowel disease (Group B), 10 steroid treated active inflammatory bowel disease patients (Group C), or 10 patients with miscellaneous gastrointestinal and liver diseases (Group D). By contrast, the 15 patients with active inflammatory bowel disease untreated with steroids (Group A) had significantly higher proportions of T4 $(+)$ cells, lower proportions of T8 $(+)$ cells, and hence higher 'helper/ suppressor' ratios than did normal controls or any of the other patient groups $(p<0 \cdot 001)$. Table 2 indicates that these alterations in 'helper/suppressor' proportions among group A patients were attributable primarily to significant decreases in absolute numbers of T8 $(+)$ cells, occurring in both Crohn's disease and ulcerative colitis $(\mathrm{p}<0 \cdot 05)$.

The Figure shows the distribution of individual 'helper/suppressor' ratios among all 62 subjects in this study. The upper limit of normal ratios among our group E subjects was $2 \cdot 5$, and this limit completely separated all 12 normal controls from all 15 active inflammatory bowel disease patients in group A. The more generally accepted ${ }^{6}$ upper limit of normal 'helper/suppressor' ratio, 3.0, separated 
Table 1 T-lymphocyte characteristics in inflammatory bowel disease (IBD) and controls

\begin{tabular}{|c|c|c|c|c|c|c|c|}
\hline \multirow[b]{2}{*}{ Patient group } & \multirow[b]{2}{*}{$\begin{array}{l}\text { Patients } \\
\text { (no) }\end{array}$} & \multirow[b]{2}{*}{$\begin{array}{l}\text { Mean age } \\
\text { (range) }\end{array}$} & \multirow[b]{2}{*}{$\begin{array}{l}\text { Sex ratio } \\
(M / F)\end{array}$} & \multirow[b]{2}{*}{$C D / U C$} & \multicolumn{2}{|c|}{$\begin{array}{l}\text { Proportions reacting with } \\
\text { monoclonal antibodies } \\
(\text { mean } \pm S D)(\%)\end{array}$} & \multirow[b]{2}{*}{$\begin{array}{l}\text { Ratio } \\
(T 4 / T 8)\end{array}$} \\
\hline & & & & & $\begin{array}{l}\text { Anti-helper } \\
\text { (anti-T4) }\end{array}$ & $\begin{array}{l}\text { Anti-suppressor } \\
\text { (anti-T8) }\end{array}$ & \\
\hline $\begin{array}{l}\text { A Active IBD } \\
\text { No steroids }\end{array}$ & 15 & $31(22-54)$ & $4 / 11$ & $10 / 5$ & $69 \pm 8 \cdot 8$ & $18 \pm 4 \cdot 5^{*}$ & $3 \cdot 83^{*}$ \\
\hline $\begin{array}{l}\text { B Active IBD } \\
\text { On steroids }\end{array}$ & 15 & $30(18-80)$ & $9 / 6$ & $12 / 3$ & $60 \pm 11 \cdot 8$ & $33 \pm 9 \cdot 5$ & $1 \cdot 82$ \\
\hline C Inactive IBD & 10 & $38(19-62)$ & $6 / 4$ & $6 / 4$ & $59 \pm 5$ & $30 \pm 5 \cdot 9$ & 1.97 \\
\hline D Disease controls & 10 & $40(15-72)$ & $6 / 4$ & - & $56 \pm 13 \cdot 4$ & $36 \pm 14$ & $1 \cdot 56$ \\
\hline E Normal controls & 12 & $37(30-56)$ & $4 / 8$ & - & $58 \pm 4 \cdot 4$ & $32 \pm 7 \cdot 1$ & $1 \cdot 81$ \\
\hline
\end{tabular}

* Significant difference from each of the other groups: $p<0 \cdot 001$. CD: Crohn's disease, UC: ulcerative colitis.

10 of 15 group A patients from 13 of 15 group B patients and from all 32 subjects in the other three groups.

Serial samples were taken in four patients to determine whether the relative proportions of the T-cell sublineages in a given patient varied during periods of differing disease activity. In one patient with ileocolic Crohn's disease, the ratio one month after complete resection of all involved bowel was $1 \cdot 8$. One year later, after severa! months of recurrence at the anastomosis, the ratio was $3 \cdot 8$. A second patient with active granulomatous ileocolitis had a ratio of 3.5 ; nine months later, after a remission had been induced on metronidazole and sulphasalazine, her ratio had fallen to $1 \cdot 7$. A third patient with Crohn's disease had a ratio of 5.3 before surgery, $2 \cdot 3$ one week after ileocolic resection, and 6.9 after recurrence of disease six months postoperatively. One patient with mild ulcerative proctitis had a ratio of $4 \cdot 0$ that fell to $2 \cdot 8$ in quiescence but inexplicably rose to 4.3 six months later without obvious change in his clinical condition.

\section{Discussion}

Our data indicate that patients with either active Crohn's disease or ulcerative colitis, untreated by steroids, have significant decreases in both the absolute numbers and relative proportions of their T8 $(+)$ cells. This decrease in cells of 'cytotoxic/ suppressor' phenotype was sufficient, at least in the ulcerative colitis patients, to be reflected by a significant decrease in total T-lymphocyte count (Table 2). In patients with active ulcerative colitis and Crohn's disease alike, this decrease in suppressor cells also resulted in consistent rises in the relative proportions of $\mathrm{T} 4(+)$ cells and consequently in raised 'helper/suppressor' ratios. Serial determinations in four patients suggested that these rises in 'helper/suppressor' cell ratios tended to coincide with periods of clinical exacerbation of disease. No alterations in absolute numbers or proportions of $\mathrm{T} 4(+)$ or $\mathrm{T} 8(+)$ cells were noted in steroid treated patients, patients with inactive disease, or patients with other gastrointestinal or liver disease.

While there are recognised discordances between T8/Leu 2 expression and suppressor activity of T-cells, ${ }^{19}$ the findings of this study are consistent with those of certain previous investigators. T-cell lymphopenia has been observed in some series, in agreement with the present observations, ${ }^{12} 20$ although this finding has not been universal. ${ }^{21-23}$ Using functional assays, Hodgson et al, ${ }^{24}$ Ginsburg et al $^{25}$ and Goodacre et al $^{26}$ have provided evidence

Table 2 Absolute numbers of T-cells and T-cell subsets in Crohn's disease and ulcerative colitis

\begin{tabular}{lccccc}
\hline Patient group & Number & $\begin{array}{l}\text { T-cells/cu/mm } \\
(\text { E } \text { rosettes })\end{array}$ & T4(+) & T8(+) & $\begin{array}{l}\text { Ratio } \\
(T 4+/ T 8+)\end{array}$ \\
\hline Active Crohn's disease & 10 & $987 \pm 780$ & $685 \pm 548$ & $177 \pm 173^{*}$ & $3 \cdot 87^{*}$ \\
Active ulcerative colitis & 5 & $574 \pm 273^{*}$ & $399 \pm 179$ & $115 \pm 66^{*}$ & $3 \cdot 47^{*}$ \\
Normal controls & 12 & $1071 \pm 428$ & $521 \pm 196$ & $340 \pm 141$ & $1 \cdot 53$ \\
\hline
\end{tabular}

Results are mean \pm SD. ${ }^{*}$ Significant difference from controls: $p<0 \cdot(05$. 


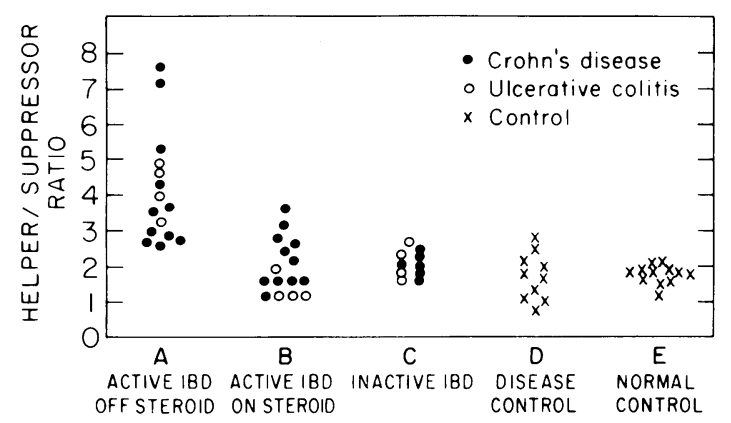

Figure T4/T8 T-cell ratios in 40 patients with inflammatory bowel disease (IBD) and 22 control subjects. Ratios are significantly raised only in the non-steroid treated patients with IBD, Crohn's disease, and ulcerative colitis alike.

of diminution in suppressor cell activity in both blood and intestinal tissue lymphocytes from Crohn's disease patients; however, with a different assay, opposite conclusions have been reached. ${ }^{27}$ Previous studies of $\mathrm{T}$-cell sublineages defined by monoclonal antibodies have likewise reached disparate conclusions. ${ }^{28-30}$

The findings of the present study provide one possible explanation of some of these divergences in reported results. Alterations in T-cell sublineages might be partly dependent upon clinical status at the time of study. In the present series, for example, patients with mild or inactive disease, and the subset of patients with active disease treated by prednisone, had lymphocyte populations not detectably different from those of the normal control group. In contrast, patients classified as having active disease but not receiving steroid therapy had consistent abnormalities in the proportions of T-cells in the two sublineages characterised by either $\mathrm{T} 4$ or $\mathrm{T} 8$ antigen expression.

There were no significant differences in the findings between patients with ulcerative colitis and those with Crohn's disease. Similarities in cellular immune aberrations between these two diseases have often been noted by us ${ }^{12} 31$ and others in previous studies. ${ }^{1}$ The immunologic parallels between ulcerative colitis and Crohn's disease, however, need not necessarily be interpreted as suggesting a similar primary pathogenesis for the two diseases, as the precise mechanisms for the diminution of circulating T8 $(+)$ cells in active cases are unknown. One possible mechanism could be selective pooling of these cells in the bowel wall at sites of tissue injury, although definitive evidence for this hypothesis is currently lacking. ${ }^{26}{ }^{32}$ Alternatively, T8 $(+)$ cells might be depleted by the action of lymphocytotoxic antibodies, which are cold-reacting auto-antibodies of the IgM class that have been described in inflammatory bowel disease. ${ }^{33} 34$ To elucidate these possible mechanisms, further studies of blood and tissue lymphocytes appear warranted, particularly in patients with defined activities of disease.

\section{References}

1 Sachar DB, Auslander MO, Walfish JS. Aetiological theories of inflammatory bowel disease. Clin Gastroenterol 1980; 9: 231-57.

2 Kirsner JB, Shorter RG. The immunology of ulcerative colitis and Crohn's disease: clinical and humoral aspects. In Inflammatory Bowel Disease. Philadelphia: Lea and Febiger, 1980.

3 Kirsner JB, Shorter RG. Recent developments in nonspecific inflammatory bowel disease: etiology and pathogenesis. $N$ Engl J Med 1982; 306: 837-48.

4 Reinherz EL, Schlossman SF. Regulation of the immune response: inducer and suppressor $\mathrm{T}$ lymphocyte subsets in human beings. $N$ Engl $\mathrm{J} \mathrm{Med}$ 1980; 303: 370-3.

5 Hunninghake GW, Crystal RG. Pulmonary sarcoidosis: a disorder mediated by excess helper Tlymphocyte activity at sites of disease activity. $N$ Engl J Med 1981; 305: 429-34.

6 Reinherz EL, Weiner HL, Hauser SL, Cohen JA, Distaso JA, Schlossman SF. Loss of suppressor T-cells in active multiple sclerosis: analysis with monoclonal antibodies. $N$ Engl J Med 1980; 303: 125-9.

7 Morimoto C, Reinherz EL, Schlossman SF. Alterations in immuno-regulatory $\mathrm{T}$-cell subsets in active systemic lupus erythematosus. J Clin Invest 1980; 66: 1171-4.

8 James SP, Elson CO, Jones EA, Strober W. Abnormal regulation of immunoglobulin synthesis in vitro in primary biliary cirrhosis. Gastroenterology 1980; 79: 242-4.

9 Smolen JS, Chusel TM, Leiserson WM, Reeves JP, Alling D, Steinberg AD. Heterogeneity of immunoregulatory $\mathrm{T}$-cell subsets in systemic lupus erythematosus: correlation with clinical features. $\mathrm{Am} \mathrm{J}$ Med 1982; 72: 783-90.

10 Marshak RH, Lindner AE, Janowitz HD. Granulomatous ileocolitis. Gut 1966; 7: 258-84.

11 Waye $\mathbf{J}$. The role of colonoscopy in the differential diagnosis of inflammatory bowel disease. Gastrointest Endosc 1977; 23: 150-4.

12 Meyers S, Sachar DB, Taub RN, Janowitz HD. Anergy to dinitrochlorobenzene and depression of $\mathrm{T}$ lymphocytes in Crohn's disease and ulcerative colitis. Gut 1976; 17: 911-5.

13 Wyban J, Carr MC, Fudenberg HH. The human rosette-forming cell as a marker of a population of thymus-derived cells. J Clin Invest 1972; 51: 2537-43.

14 Kung PC, Goldstein G, Reinherz EL, Schlossman SF. 
Monoclonal antibodies defining distinctive human Tcell surface antigens. Science 1979; 206: 347-9.

15 Reinherz EL, Kung PC, Goldstein G, Schlossman SF. A monoclonal antibody with selective reactivity with functionally mature human thymocytes and all peripheral human T-cells. J Immunol 1979; 123: 1312-7.

16 Reinherz EL, Kung PC, Goldstein G, Schlossman SF. Separation of functional subsets of human T-cells by a monoclonal antibody. Proc Natl Acad Sci USA 1979; 76: 4061-5.

17 Reinherz EL, Kung PC, Goldstein G. Schlossman SF. Further characterization of the human inducer $\mathrm{T}$-cell subset defined by monoclonal antibody. J Immunol 1979; 123: 2894-6.

18 Reinherz EL, King PC, Goldstein G, Schlossman SF. A monoclonal antibody reactive with the human cytotoxic/suppressor T-cell subset previously defined by a heteroantiserum termed $\mathrm{TH}_{2}$. J Immunol 1980: 124: 1301-7.

19 Alexander GJM, Nouri-Aria KT, Eddleston ALWF. Williams $\mathrm{R}$. Contrasting relations between suppressorcell function and suppressor-cell number in chronic liver disease. Lancet 1983; 1: 1291-3.

20 Strickland RG, Husby G. Black WC, Williams RC. Peripheral blood and intestinal lymphocyte subpopulations in Crohn's disease. Gut 1975; 16: 847-53.

21 Auer IO, Weschler W, Ziemer E, Malchow H, Sommer H. Immune status in Crohn's disease. 1. Leucocyte and lymphocyte subpopulations in peripheral blood. Scand J Gastroenterol 1978; 13: 561-71.

22 Auer IO, Buschmann $\mathrm{CH}$, Ziemer E. Immune status in Crohn's disease. 2. Originally unimpaired primary cell medicated immunity in vitro. Gut 1978; 19: 618-26.

23 Victorino RMM, Hodgson HJF. Alteration in Tlymphocyte subpopulations in inflammatory bowel disease. Clin Exp Immunol 1980; 41: 156-65.

24 Hodgson HJF, Wands JR. Isselbacher KJ. Decreased suppressor activity in inflammatory bowel disease. Clin Exp Immunol 1978; 32: 451-8.

25 Ginsburg $\mathrm{CH}$. Falchuk ZM. Defective autologous mixed-lymphocyte reaction and suppressor cell generation in patients with inflammatory bowel disease. Gastroenterology 1982; 83: 1-9.

26 Goodacre RL. Bienenstock J. Reduced suppressor cell activity in intestinal lymphocytes from patients with Crohn's disease. Gastroenterology 1982; 82: 653-8.

27 Elson CO, Graeff AS, James SP, Strober W. Covert suppressor T-cells in Crohn's disease. Gastroenterolog. 1981; 80: 1513-21.

28 James SP, Graeff AS, Cossman J. Neckers LM, Strober W. Deficiency of helper/inducer T-cell subset in patients with mild Crohn's disease. Gastroenterology 1982; 82: 1092.

29 Hanauer SB, Kluskens LE, Yuan SZ, Kraft SC. Monoclonal antibody studies of circulating lymphocytes in Crohn's disease. Gastroenterology 1982; 5: 1079.

30 Pepys EO, Fagan EA, Tennent GA, Chadwick VS, Pepys MB. Enumeration of lymphocyte populations defined by surface markers in the whole blood of patients with Crohn's disease. Gut 1982; 23: 766-9.

31 Sachar DB. Taub RN, Brown SM et al. Impaired lymphocyte responsiveness in inflammatory bowel disease. Gastroenterology 1973; 64: 203-9.

32 Fiocchi C. Battisto JR, Farmer RG. Gut mucosal lymphocytes in inflammatory bowel disease: isolation and preliminary functional characterization. Dig Dis Sci 1979; 24: 705-17.

33 Korsmeyer S, Strickland RG, Wilson ID. Serum lymphocytotoxic and lymphocytophilic antibody activity in inflammatory bowel disease. Gastroenterology 1974; 67: 578-83.

34 Korsmeyer S. Williams RC, Wilson ID, Strickland RG. Lymphocytotoxic antibody in inflammatory bowel disease: a family study. $N$ Engl J Med 1975; 293: 1117-20. 